\title{
EFFECT OF INCREASE IN TEMPERATURE ON THE SURVIVAL AND GROWTH OF MACROBRACHIUM AMAZONICUM (HELLER 1862) IN THE AMAZON
}

\author{
Bastos, A.M. ${ }^{1,2,}{ }^{*}$, Lima, J.F. ${ }^{2}$ \& Tavares-Dias, M. $^{2}$ \\ ${ }^{1}$ Federal Institute of Education, Science and Technology of Amapá (IFAP), Macapá campus. Department of Physics. \\ ${ }^{2}$ Brazilian Agricultural Research Corporation (Embrapa) Amapá, Macapá, AP. Carciniculture Laboratory. \\ *Corresponding author: argemiro.bastos@ifap.edu.br
}

\begin{abstract}
Macrobrachium amazonicum is a shrimp species distributed in freshwater habitats of Neotropical regions and is important for the Amazonian economy. This study evaluated the effects of temperature increase on the survival and growth of M. amazonicum. For this, we distributed $360 \mathrm{M}$. amazonicum juveniles in $70 \mathrm{~L}$ tanks and carried out a 90-day experiment with three treatments (T0: $28.0 \pm 0.5^{\circ} \mathrm{C}$, or room temperature; $\mathrm{T} 1: 30.0 \pm 0.2{ }^{\circ} \mathrm{C}$; T2: $32.0 \pm 0.2{ }^{\circ} \mathrm{C}$ ), using 4 replicate tanks each with 30 individual shrimps. Culture-tanks were connected to a recirculation system with biofiltration and constant aeration. Animals were fed twice a day using shrimp pelleted commercial food. After 90 days, there was difference in growth rate in length (T0=74.7 $\pm 4.7 \%$, $\mathrm{T} 1=65.9$ $\pm 5.6 \% ; \mathrm{T} 2=64.6 \pm 5.6 \%)$ and body mass gain ( $\mathrm{T} 0=433 \pm 46 \%, \mathrm{~T} 1=371 \pm 40 \% ; \mathrm{T} 2=348 \pm 54 \%)$ of the animals cultured. According to the Dunn test, the specific growth rate (T0=11.0 $\pm 0.6 \%, \mathrm{~T} 1=8.8 \pm 1.1 \%$; $\mathrm{T} 2$ $=8.3 \pm 1.07 \%)$, condition factor $(\mathrm{T} 0=1.00 \pm 0.002, \mathrm{~T} 1=0.98 \pm 0.009 ; \mathrm{T} 2=0.97 \pm 0.016)$, weight gain $(\mathrm{T} 0=$ $0.99 \pm 0.05 \mathrm{~g}, \mathrm{~T} 1=0.80 \pm 0.10 \mathrm{~g} ; \mathrm{T} 2=0.74 \pm 0.01 \mathrm{~g})$, length gain $(\mathrm{T} 0=71.49 \pm 1.65 \mathrm{~mm}, \mathrm{~T} 1=65.81 \pm 1.85$ $\mathrm{mm} ; \mathrm{T} 2=64.49 \pm 1.48 \mathrm{~mm}$ ) and survival ( $\mathrm{T} 0=78.7 \pm 8.9 \%, \mathrm{~T} 1=65.2 \pm 9.7 \% ; \mathrm{T} 2=36.5 \pm 9.1 \%$ ) of animals cultured at $30.0{ }^{\circ} \mathrm{C}$ and $32.0{ }^{\circ} \mathrm{C}$ were lower than those cultivated at $28.0{ }^{\circ} \mathrm{C}$, and feed conversion $(\mathrm{T} 0=2.7 \pm$ $0.03, \mathrm{~T} 1=2.9 \pm 0.15 ; \mathrm{T} 2=2.9 \pm 0.16$ ) was higher. Therefore, as water temperature of $30.0{ }^{\circ} \mathrm{C}$ and $32.0{ }^{\circ} \mathrm{C}$ may compromise growth and survival of $M$. amazonicum during cultivation, none of the extreme temperatures are recommended in practice. The effects of increasing temperature in the Amazon and its consequences on the development of $M$. amazonicum populations were also discussed here.
\end{abstract}

Keywords: cultivation, growth, shrimp, survival, temperature. 